\title{
Management Based on the Marketing Strategies with EU Standards - Case Study Peja Brewery
}

\author{
Hajrija Škrijelj \\ University "Haxhi Zeka"-Peja \\ hajrija.skrijelj@unhz.eu \\ Ibish Mazreku \\ University "Haxhi Zeka"-Peja \\ ibish.mazreku@unhz.eu \\ Duda Balje \\ University "Ukshin Hoti"-Prizren \\ duda.balje@hotmail.com
}

\section{Doi:10.5901/ajis.2015.v4n2s1p108}

\section{Abstract}

\begin{abstract}
Management is a universal tool, a necessary tool of the modern industrial world. Every organization, every small or more complex work or other serious activities, require management to lead to the selected target, or to be finished effectively. Modern organization, economic or non-economic, require constant management actions that would act and evolve in a complex and dynamic environment in which they operate. Management is a phenomenon of our time, a necessity of modern life and work and it is widespreading and growing rapidly. Management is necessary for the efficient functioning and development of each company, each social system and society as a whole, for more efficient performance of any complex work and enterprise. Operator approach to solving various problems is the basic characteristic of modern management, modern scientific discipline without which it is impossible to operate efficiently, function and develop. Management is becoming increasingly important as work becomes more specialized and complex, as it multiplies the scope of activities to be carried out and the number of organizations and individuals that these activities are prepared and executed. Rapid technological development emphasizes the need to use management methods and approaches, and the use of management as a scientific discipline that deals with the management of business systems and processes, and management of all organized systems, in order to improve their efficiency. From the standpoint of the company, demand the functional relationship that indicates the amount of certain products that could be bought at different prices in a given place and a certain time. Analysis of demand should provide information on the approximate price that buyers are willing to pay for company's products and services. The demand curve of economic theory, which, in economic practice found application as an analytical framework for making decisions on prices and has a negative slope. Specifically, its movement points to the phenomenon that if the prices are lower, the demand increases and vice versa.
\end{abstract}

Keywords: Functions of management,: Planning, Organization, Leadership and management, Control.

\section{Introduction}

Management represents a universal, means necessary tools, of modern industrial world. Any organization, any remotely complex work or serious activity, requiring management to lead to a selected target, or to effectively finished. Modern organization, economic or non-economic, requiring constant management actions that would act and evolve in a complex and dynamic environment in which they operate. The research objectives are manifold, but the overall goal is related to the analysis and prediction of final consumer demand in the market Peja Brewery. The research team of students in this research is to determine the satisfaction and consumer reaction to these changes. The final results we will get data analysis conducted surveys will be used for acceptance or rejection of the null and alternative hypotheses in the following format: Ho - Consumers are not satisfied with the product Peja Brewery (Birra Peja) H1 - Consumers are satisfied with the product Peja Brewery (Birra Peja) Objectives are as follows: To investigate the reasons why consumers opted for PEJA beer and the reasons why they opt for the purchase of competing products. Identify customer satisfaction altered 
design taste and packaging. To determine the level of satisfaction with existing prices. To determine the availability of Peja beer in retail and wholesale facilities in the town of Peja. Identify consumer awareness of the existence of promotional activities Peja Brewery. For the realization of the goals of the research will be used the available secondary data sources (data management Peja Brewery, internet). In addition to the secondary, it is necessary to collect primary data from consumers Peja beer. For data collection method will use an oral examination, and as a means of collecting data use the questionnaire. Due to the operational goals of the research is necessary to questions in the questionnaire are as concrete as possible for reasons of obtaining more precise data relating to each producer individually. Questions are konstrolisana to yield the desired information, that ice enable us to respond to the problem. The collected data will be analyzed using qualitative and quantitative statistical analysis techniques with the use of appropriate software (SPSS, Excel). Primary data collection will be carried out on the basis of an intentional sample size of 100 respondents who consume beer. Respondents in the sample ice to be secured in a manner that ice $50 \%$ of respondents to be the younger population (under $35 \mathrm{yr}$.), And $50 \%$ of older adults (from 35 and more years.).

\section{Management Control and Management of the Company}

Management as a discipline began to be studied in 1911, and with us only in 1990. Under the management of the most common involves knowledge about the upravljnju enterprise as the organizational system. Management is the process of deciding on the goals of the organizational system and the way of its realization. Management is the process of working with people with the inclusion of other organizational resources. Mary Parker Foley gave the definition of management as follows: "The management skills of work through other people." The basic functions of management: planning, organizing, leadership or direction and control.

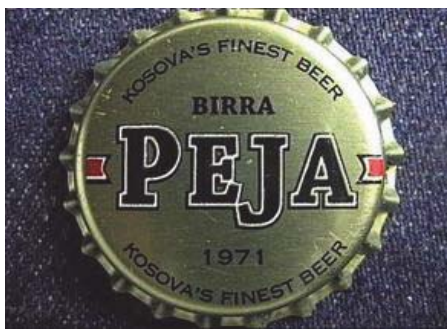

Control of the management activity that requires monitoring, evaluation, measurement and improvement of various activities in the organization with a view to identifying the effects and take correction, if necessary, in relation to the planned goals and tasks, and established norms or standards of business and organizational development. The secret of success of each leading companies in the world largely lies in the strong control of critical business operations. With wellconfigured control system, the company managed to increase their competitive ability, develop good products and services and provide a high degree of consistency in the provision of services. The concept of control is defined in ways protects. To control the happiness and different terms, such as verification, supervision, testing, monitoring, evaluation, monitoring, regulation, etc. Unlike some other concepts in management, among experts there are no substantial differences in terms of understanding its essence. The importance of the control system for the organization, we can see when it is not properly designed.

Then problems arise that indicate the obvious omissions in the organization:

- Poor quality products and services

- delay in reporting,

- decline or stagnation of profit,

- poor work ethic and a very bad human relations,

- loss of leadership positions in the market and a reduction of orders by customers,

- impossibility of rapid and timely obtaining of relevant data and information,

- inefficient use of resources, etc. 


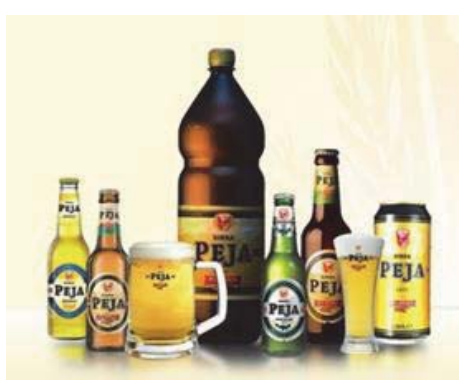

Managers would be pleased if we could formulate such goals that would automatically set the standards in control. Objectives must be clear and specified, give in a quantitative form (preferably quantitative) and with precise deadlines that could be used as standards in control. However, in practice there are many problems in establishing the standards. Standards in control can be defined as goals, objectives or results to be achieved in a given period of time. Since their formulation depends on the efficiency of the entire process control. Standards can take different indicators.

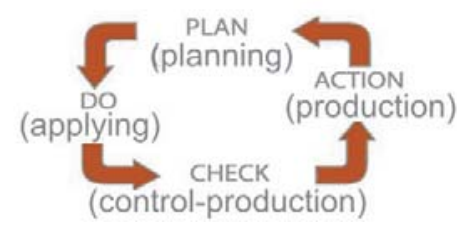

\subsection{Connection planning and control}

Connection planning and control All standards can be classified into one of the following four groups: $\bullet$ quantitative, such as physical, which are used to control material inputs, • qualitative, which can be sometimes intangible; $\bullet$ financial, to supervise the operations in monetary units - can be expressed as cost, revenue, or profits; • Time, which can not be clearly defined deadlines for carrying out certain activities. The survey of customer satisfaction their product Peja Brewery Birra Peja (PEJA beer) in the town of Peja. Given the drop in sales recorded last few years, Peja Brewery introduces changes in the taste of the design and packaging of Peja beer. The research team of students in this project is to determine consumer satisfaction and response to these changes. The final results we will get data analysis conducted surveys will be used for acceptance or rejection of the null and alternative hypotheses in the following format: Ho Consumers are not satisfied with the product PEJA beer (Birra Peja) H1 - Consumers are satisfied with the product PEJA beer (Birra Peja) Scientific establish customer satisfaction by Peja beer, as well as their reactions to the changed layout, design, taste and packaging of the product. The research objectives are manifold, but the overall goal is to collect information on consumer satisfaction Peja Brewery quality products Peja beer, which could be used in the management company decision making when creating a new business policy. The operational objectives are as follows: $\bullet$ Examine the reasons why consumers opted for PEJA beer and the reasons why they opt for the purchase of competing products; • Identify customer satisfaction altered taste and packaging design; - Determine the level of satisfaction with existing prices; • Determine the availability of Peja beer in retail and wholesale facilities in the town of Peja

\section{Analysis of Collected Data Descriptive Analysis of Data Collected}

In this section we will present a graphic and descriptive presentation of the collected data (response) obtained to the questions in the questionnaire. The first question in the questionnaire was selective in which respondents answered the question whether PEJA consume beer.

\begin{tabular}{|c|c|}
\hline Do you consume beer PEJA? & \multicolumn{1}{|c}{} \\
\hline Yes & 100 \\
\hline No & 0 \\
\hline$\Sigma$ & 100 \\
\hline
\end{tabular}




\section{The Consumption of Beer Peja}

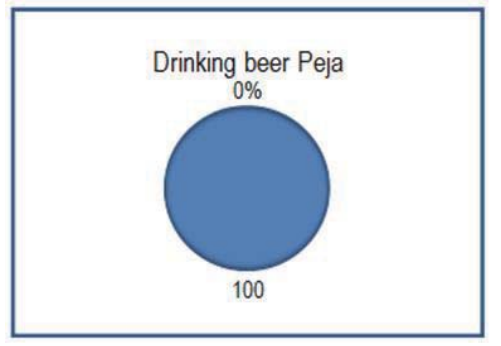

\section{Conclusion}

"The world is a global village" is known for saying Marshall McLuhan that means a period of rise of the Internet and its impact on daily life. This is well-connected world presents much more favorable terms of advertising products, the possibility that any person in any part of the world is made aware of the same product, which is a big advantage, but equally a disadvantage because it is now being challenged by advertisers, stronger than ever, as are the requirements consumers placed at a higher level. Various innovations in management are born every day, but do not find any clear road to the entrenched by consumers due to the enormous amount of information that reaches consumers. This congestion information makes it difficult for most of the information to be registered, so that the notice only ones that stand out from the rest! Creativity and innovation provide freedom, born ambition and create dynamic, i.e. Pushing the world forward. Same innovations are not self-sufficient, so they have a good and targeted promotion to arouse desire and interest among consumers. Today's consumers require that communications reach synergy effects, and to transmit the same meaning all forms of promotion. In other words, they require communication mix that will most effectively communicate the desired message, create a high brand equity, a desirable image and long-term brand loyalty products.Today oglašavateljima can use a large variety of media advertising that its characteristics, advantages and disadvantages of doing, or not, appropriate media for dissemination of information about a particular product or service. In addition to the importance and the main features of e-marketing, this paper attempts to describe the importance of innovation and the need for companies to be innovative. Although it has some shortcomings, they are seen as the initiators of continuous improvement. These products give us back hope in Kosovo innovation and their strength, the possibility of expulsion importers from the market and strong penetration into international markets.

From interviews with respondents, we concluded that when choosing Peja beer is not present local patriotism. As we have already mentioned the selection of Peja beer quality in the first place, and the price is also very important. The last operational objective was to investigate basic product defects Peja beer. The data analysis revealed that the range of products the main disadvantage of Peja beer, and participants showed great dissatisfaction and promotional activities Peja Brewery.

We think that, in addition to the above proposals, the Peja Brewery need the following:

- Expansion of the range Peja Brewery introduction of dark beer and beer with lemon flavor

- Expansion range Peja Brewery introduction of packs of 0.251

- It is necessary to increase the number of promotional activities

- Change the tagline Peja beer.

\section{References}

D. Ružić: E-Marketing, Subotica, 2003.

S.Dvorski, D. Dobrinić: Direktni marketing, Tiva Tiskara, Varaždin, 2002.

Jozo Previšić, Bratko Frajlići: Marketing, Sinergija, 2001.

T. Kesić, Upravljanje marketingom, Adeco, Zagreb, str. 416.

I. Vlašić, Mumel Mandelli: Interaktivni marketing, Perago, Zagreb 2007. godina.

R. Pavičić, S Alfirević, I. Vlašić: Marketinška komunikacija i upravljanje novim medijima, Beograd 2004.

I. Ferenček, Počela Ekonomike, Ekonomski fakultet Osijek, 2003. 